Gut, 1989, 30, 912-916

\title{
Serum pepsinogen I and IgG antibody to Campylobacter pylori in non-specific abdominal pain in childhood
}

\author{
GIUSEPPINA ODERDA, D VAIRA, J HOLTON, J F DOWSETT, \\ AND NICOLETTA ANSALDI \\ From the Pediatric Gastroenterology Section, University of Torino, Italy and Departments of Gastroenterology \\ and Microbiology, The Middlesex Hospital, London
}

SUMmary A consecutive series of 51 children (mean age 11 years) who presented with recurrent abdominal pain were investigated by upper gastrointestinal endoscopy including three antral biopsies for microscopy, culture and urease testing. Serum IgG, IgA, and IgM antibodies to Campylobacter pylori ( $C$ pylori) were measured by the ELISA technique. Serum pepsinogen I was also measured. Thirty two children showed histological evidence of gastritis. All had $C$ pylori on microscopy and or culture. Nineteen children showed no histological gastritis nor evidence of $C$ pylori on microscopy, culture and/or urease testing. The IgG and IgA antibody levels to $C$ pylori were significantly higher in $C$ pylori positive children than in the negative group $(p<0 \cdot 001)$. Serum pepsinogen I concentrations were also significantly higher in $C$ pylori positive children than in negative $(\mathrm{p}<0 \cdot 001)$. Measurement of IgG antibody levels, combined with serum pepsinogen I estimation, predict the presence of $C$ pylori associated gastritis in children with a sensitivity and specificity of up to $95 \%$. It may be used therefore to predict gastritis and even peptic ulceration in children presenting with non-specific upper abdominal pain.

A strong association is now recognised in adults ${ }^{1}$ between the presence of Campylobacter pylori ( $C$ pylori) in gastric mucosa and histologically confirmed gastritis. The question remains, however, whether $C$ pylori is involved in the pathogenesis of acute or chronic gastritis, or is merely a commensal. $C$ pylori also has been reported to be specifically associated with primary antral gastritis in children and as in adults, the organism is only present in the gastric mucosa in concert with gastric inflammation. ${ }^{2}$ Raised serum pepsinogen $I$ is found in about twothirds of adult patients with peptic disease, ${ }^{3}$ and is thought to be a useful subclinical marker of genetic predisposition to ulceration. ${ }^{4}$ Serum pepsinogen I has recently been found to be raised in children with C pylori associated gastritis. ${ }^{5}$

Address for correspondence: Dr Dino Vaira, MD, Ist Medical Clinic, University of Bologna, S Orsola Hospital, Nuove Patologie, Via Massarenti 9. 40138 Bologna, Italy.

Accepted for publication 8 November 1988.
We report the findings of a prospective study in which we used Giemsa staining, culture, and urease testing of antral biospy specimens obtained from children undergoing upper gastrointestinal endoscopy as investigation of upper abdominal pain. We compared them with serum IgG, $\operatorname{IgA}$, and $\operatorname{IgM}$ and serum pepsinogen $I$ in order to assess the value of determination of these serological markers as a noninvasive guide to $C$ pylori associated gastritis.

\section{Methods}

PATIENTS

Over a one year period, antral biopsies were obtained from 51 children undergoing upper gastrointestinal endoscopy for investigation of upper abdominal pain being evaluated from the presence of $C$ pylori. Ages ranged from 1 to 18 years (mean 11). None of the children had received any medication which might affect gastric acidity before endoscopy. 
Fully informed parental consent was obtained before all endoscopies and biopsies.

\section{ENDOSCOPY}

Oesophagogastroduodenoscopy was performed under diazepam sedation using an Olympus GIF P3 gastroscope. The endoscope and biopsy forceps were disinfected in $2 \%$ glutaraldehyde after each use.

\section{HISTOLOGY}

Specimens were immediately fixed in $10 \%$ buffered formalin and stained with haematoxylin and eosin to determine the presence of gastritis, as described by Whitehead et al..$^{6}$ Colonising $C$ pylori was identified by Giemsa staining. The classification of gastritis was made without knowledge of the results of the Giemsa staining, culture, or urease testing.

\section{CULTURE}

The specimens were placed in $0.5 \mathrm{ml} 20 \%$ sterile glucose. All were then processed within two hours and homogenised in $0.2 \mathrm{ml}$ sterile water and then cultured on blood agar with amphotericin. They were incubated in a microaerobic environment at $37^{\circ} \mathrm{C}$ and examined after six days. $C$ pylori colonies (small and grey) were tested for oxidase and urease and confirmed by Gram staining.

UREASE TEST

Before endoscopy, the CLOtest (Delta-West Ltd) was warmed to $30^{\circ} \mathrm{C}$ in an incubator or in the endoscopist's pocket as Marshall recommended.? A $2 \mathrm{~mm}$ pinch biopsy was taken from antral mucosa and the tissue pushed beneath the surface of the CLOtest gels.

\section{ENZYME LINKED IMMUNOSORBENT ASSAY}

(ELISA)

C pylori isolated previously from one of our patients (B1) was used as the source of antigen. It was grown on blood agar, harvested, and sonicated for five minutes suspended in phosphate buffered saline. The sonicate was then centrifuged at $25000 \mathrm{~g}$ for 30 minutes and the supernatant used after a proper dilution as the antigen preparation in a standard ELISA technique. The antigen preparation was added to each well and incubated for two hours at $37^{\circ} \mathrm{C}$. The plates were washed with washing buffer and binding sites were blocked by adding $2 \%$ serum albumin in washing buffer and incubated for 18 hours at $4^{\circ} \mathrm{C}$. Diluted serum was added to each well and incubated for 90 minutes at $37^{\circ} \mathrm{C}$. The plates were washed again and peroxidase linked $\operatorname{IgG}, \operatorname{IgA}$, and IgM conjugate was added and incubated for two hours at $4^{\circ} \mathrm{C}$. The plates were washed again and substrate was added and left for 45 minutes in a dark room and finally stopping solution was placed and the optical density of the wells was read at $470 \mathrm{~nm}$ using a MICROELISA plate reader.

SERUM PEPSINOGEN I

After an overnight fast, blood was drawn at 9 am and serum pepsinogen I concentrations were determined by radioimmunoassay (RIA) using a commercial kit (Pepsik, SORIN Biomedica, Saluggia, Italy). Results are given as $\mathrm{ng} / \mathrm{ml}$. The $99 \%$ confidence interval of serum pepsinogen I concentrations in a normal paediatric population have been previously studied $^{\mathrm{x}}(43 \cdot 2-56 \cdot 7 \mathrm{ng} / \mathrm{ml}$; mean $=49 \cdot 9, \mathrm{SD}=9 \cdot 8$, $97 \mathrm{th}$ centile $=69 \cdot 5 \mathrm{ng} / \mathrm{ml}$ ). A serum pepsinogen I level higher than $56.7 \mathrm{ng} / \mathrm{ml}$ was considered to be above normal.

STATISTICAL ANALYSIS

Statistical analysis by two tailed Mann-Whitney U-test was used.

\section{Results}

Table 1 shows the endoscopic findings in the children. Table 2 shows the results of histology, microscopy, culture, and urease testing in antral biopsy specimens obtained from 51 children. Thirty two of the specimens showed histological evidence of primary gastritis including all seven with chronic peptic ulceration. No children had secondary gastritis. The inflammatory infiltrate was generally mixed, consisting of plasma cells, lymphocytes and polymorphonuclear leucocytes. All 32 also had $C$ pylori on microscopy. The remaining 19 antral specimens had normal histological features without evidence of gastritis or presence of $C$ pylori on Giemsa staining, culture or urease teting. C pylori was cultured in 29 of

Table 1 Endoscopy results

Normal endoscopic findings

Oesophagitis

Nodular antritis

Gastric ulcer

Duodenal ulcer

Table 2 Results of microscopy, culture and urease test for $\mathrm{C}$ pylori in antral biopsy specimens from 51 children

\begin{tabular}{|c|c|c|c|c|c|}
\hline & $\begin{array}{l}\text { Subjects } \\
\text { (n) }\end{array}$ & $\begin{array}{l}\text { Presence } \\
\text { of hist } \\
\text { gastritis }\end{array}$ & $\begin{array}{l}\text { Positive on } \\
\text { Giemsa } \\
\text { stain }\end{array}$ & $\begin{array}{l}\text { Positive } \\
\text { culture }\end{array}$ & $\begin{array}{l}\text { Positive } \\
\text { urease } \\
\text { test }\end{array}$ \\
\hline Normal children & 19 & 0 & 0 & 0 & 0 \\
\hline $\begin{array}{l}\text { Children with } \\
\text { primary gastriti }\end{array}$ & $\begin{array}{l}32 \\
\text { is }\end{array}$ & 32 & 32 & 29 & 24 \\
\hline
\end{tabular}



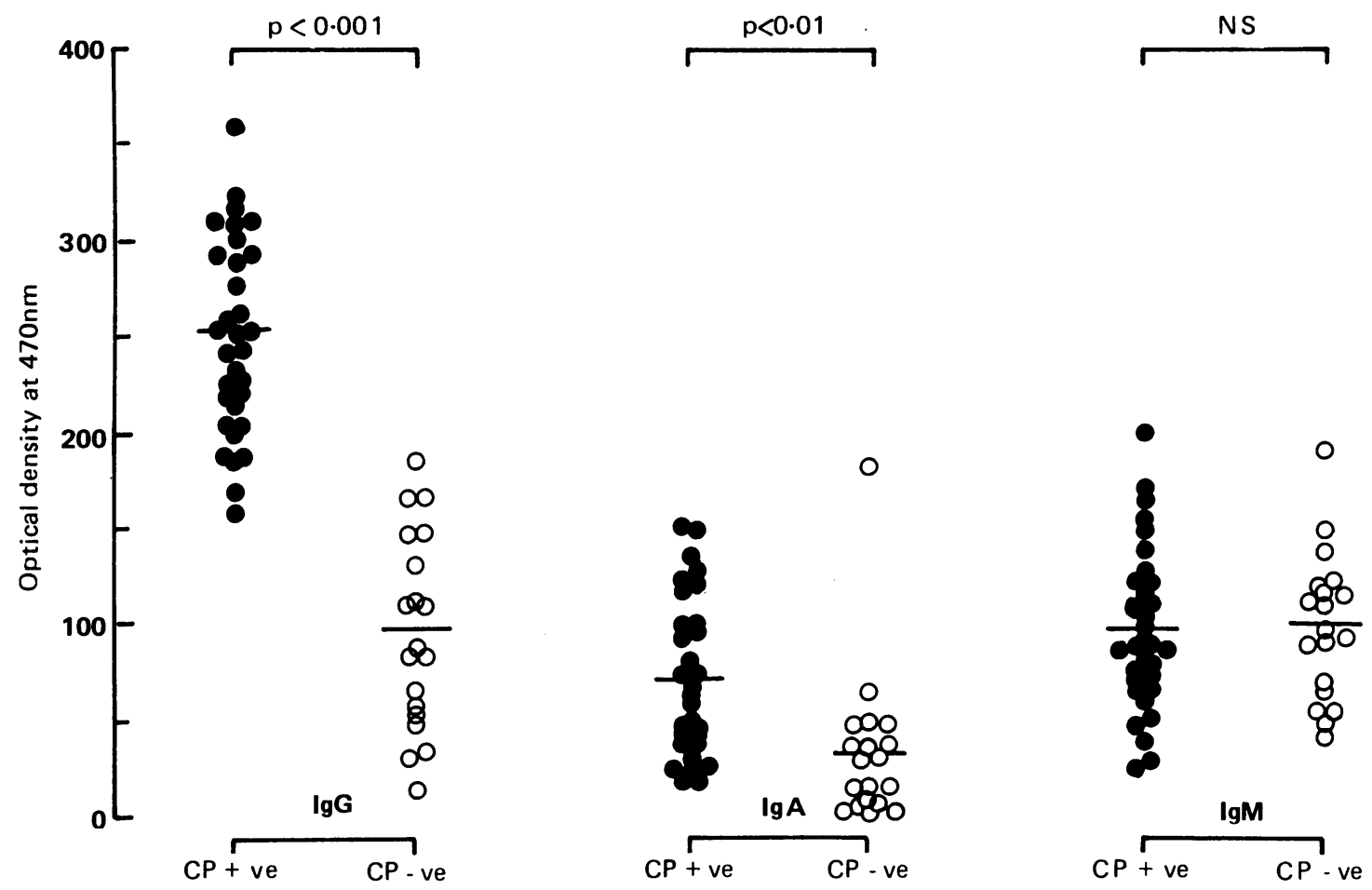

Fig. 1 Serum $\operatorname{IgG}, \operatorname{Ig} A$, and $\operatorname{IgM}$ antibody titres to $\mathrm{C}$ pylori in positive and negative children.

32 positive children (sensitivity $90 \%$ ). The urease test showed positive results in 24 of 32 positive patients (sensitivity $74 \%$ ). False positives were not observed with either technique (specificity $100 \%$ ).

$C$ pylori positive children ( $C$ pylori seen on microscopy and or culture) had significantly higher IgG and $\operatorname{IgA}$ than $C$ pylori negative patients $(\mathrm{p}<0.001$ and $\mathrm{p}<0.01$ respectively). IgM levels were not statistically different in $C$ pylori positive and negative groups (Fig. 1). Moreover, $C$ pylori positive children had significantly higher serum pepsinogen I concentrations than $C$ pylori negative patients $(\mathrm{p}<0 \cdot 001)$ (Fig. 2 ). Table 3 shows the sensitivity and the specificity of all the techniques used for the detection of $C$ pylori.

\section{Discussion}

Our results confirm that $C$ pylori is specifically associated with primary antral gastritis in children as in adults, the organism being found on the gastric mucosa only in the presence of antral inflammation as previously reported. ${ }^{2}$ Further, significantly higher $\operatorname{IgG}(\mathrm{p}<0.001)$ and $\operatorname{IgA}(\mathrm{p}<0.01)$ levels were found in children with $C$ pylori associated gastritis, again mirroring adult investigations. ${ }^{9}$ The sensitivity and specificity of IgG testing was $93 \%$.
Raised serum pepsinogen $I$ is found in patients with peptic ulcer disease. It is inherited as an autosomal dominant trait, ${ }^{10}$ is correlated with gastric acid and pepsin secretion," and may be a useful subclinical marker of genetic predisposition to peptic disease. ${ }^{4}$ Previous epidemiological studies have shown a weak but significant increase of pepsinogen I with age but this increase has only been found above the age of 30 years. ${ }^{1213}$ We have previously calculated the normal range of serum pepsinogen I in children ${ }^{8}$ and that children with $C$ pylori associated gastritis have higher concentrations of serum pepsinogen I than children without $C$ pylori associated gastritis. Furthermore it has been shown that a normal serum pepsinogen I concentration in a child with peptic disease can predict that his disease will not relapse, while a raised concentration suggests an unfavour-

Table 3 Sensitivity and specificity of all test used for the detection of $\mathrm{C}$ pylori

\begin{tabular}{|c|c|c|c|c|c|}
\hline Microscopy & & Culture & $\begin{array}{l}\text { Urease } \\
\text { test }\end{array}$ & $\operatorname{Ig} G$ & $\begin{array}{l}\text { Pepsinogen } \\
I\end{array}$ \\
\hline Sensitivity & - & $90 \%$ & $\begin{array}{r}74 \% \\
100 \%\end{array}$ & $93 \%$ & $71 \%$ \\
\hline
\end{tabular}




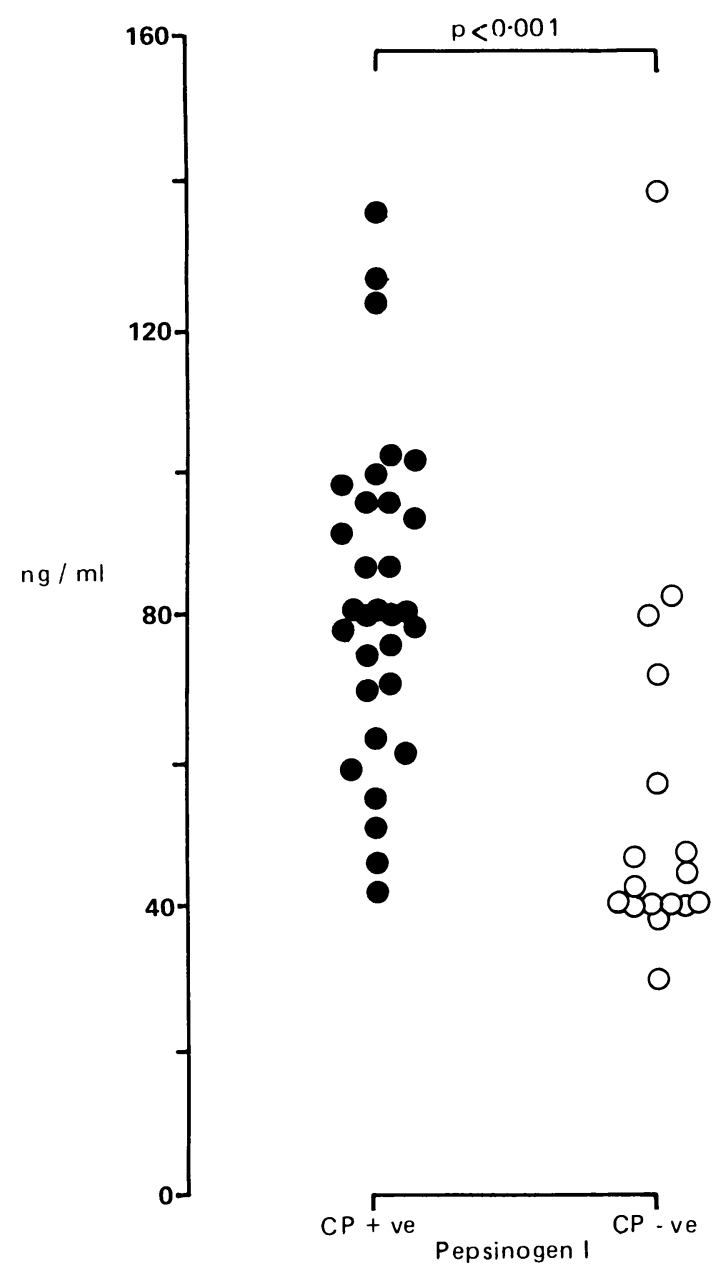

Fig. 2 Serum pepsinogen I in positive and negative children.

able outcome. ${ }^{14}$ In this paper we confirm the known rise of serum pepsinogen in children with peptic ulcer but have also shown that $C$ pylori positive children with gastritis had significantly higher serum pepsinogen I than $C$ pylori negative patients $(p<0 \cdot 001)$. The sensitivity and specificity of a raised pepsinogen I for the presence of $C$ pylori was $71 \%$.

A combination of the two serological parameters (C pylori IgG; pepsinogen I) brings the sensitivity and specificity for $C$ pylori detection up to $95 \%$. They may be used therefore to predict the associated gastritis and/or ulceration and may be of value in deciding whether to endoscope a child with nonspecific upper abdominal symptomatology. Moreover, as decrease in antibody levels with clearance of the bacteria and resolution of the histological features of gastritis is known in adults, ${ }^{15}$ antibody levels may be helpful in following response to treatment of $C$ pylori associated gastritis and peptic ulceration in children. Serology may also be used in population and longitudinal studies of the peptic ulcer diathesis.

Finally, it is tempting to speculate that as $C$ pylori is associated with gastritis and peptic ulcer disease in children, inability to completely clear the organism after initial infection could conceivably result in a gastritis-ulceration progression with age. Raised pepsinogen I could then be involved as a primary or secondary phenomenon.

We would like to thank Dr John Osborn, Senior Lecturer, London School of Hygiene and Tropical Disease for the help in performing the statistics.

\section{References}

1 Vaira D. Holton J, Cairns S, Falzon M, Salmon PR. 4 hour rapid urease test (RUT) for the detection of Campylobacter pylori (CP): is it reliable enough to start therapy? J Clin Pathol 1988; 41: 355-6.

2 Drumm B, Sherman P, Cutz E, Karmali M. Association of Campylobacter pylori on the gastric mucosa with antral gastritis in children. N Engl J Med 1987; 25: 15.5761 .

3 Samloff IM, Liebman WM, Panitch NM. Scrum group I pepsinogens by radioimmunoassay in control subjects and patients with peptic ulcer. Gastroenterology 1975; 69: $83-90$.

4 Defize J. Meuwissen SGM. Pepsinogens: an update of biochemical, physiological, and clinical aspects. J Pediatr Gastroenterol Nutr 1987; 6: 494-508.

5 Oderda G, Dell'Olio D, Lerro P, Altare F, Morra I, Ansaldi N. Campylobacter pylori (CP) and serum Pepsinogen I (PG I) in children. [Abstract.] Gut 1988; 29: A 1460 .

6 Whitehead R. Truelove SC, Gear MWL. The histological diagnosis of chronic gastritis in fiberoptic gastroscope biopsy specimens. J Clin Pathol 1972; 25: 1-11.

7 Marshall BJ, Warren JR, Francis GJ, Langton SR, Goodwin CS, Blincow ED. Rapid urease test in the management of Campylobacter pyloridis-associated gastritis. Am J Gastroenterol 1987; 82: 200-10.

8 Ansaldi N, Altare F, Farina L, Dell'Olio D, Oderda G. Serum pepsinogen $I$ in children. Its correlation with gastric acid output and serum gastrin. Ital J Pediatr 1988; 14: 156-9.

9 Vaira D. Holton J, Falzon M, et al. Investigation of Campylobacter pylori associated gastritis by histology, culture, urease tests, brushings and antibody levels. Ital J Gastroenterol 1988; 20: 299-304.

10 Rotter JI, Sones JQ, Samloff IM, et al. Duodenal-Ulcer disease associated with elevated serum pepsinogen I. An inherited autosomal dominant disorder. $N$ Engl J Med 1979; 300: 63-6.

11 Waldum HL, Straume BK, Burhol PG, Bredrup Dahl L. Serum group I pepsinogens in children. Acta Paediatr Scand 1980; 69: 215-8. 
12 Samloff MI, Licbman WM, Panitch NM. Serum group I pepsinogens in children. Acta Paediatr Scand 1980; 69: 215-8.

13 Axelsson CK, Szecsi PB, Nielsen MD. Group I pepsinogen in serum. I. Normal range, age and sex relation, diurnal rhythm, seasonal variation, and distribution in ABO blood groups. Scand J Gastroenterol 1984;
19: $1114-8$

14 Oderda G, Altare F, Dell Olio D, Ansaldi N. Prognostic value of serum pepsinogen I in children with peptic ulcer. J Pediatr Gastroenterol Nutr 1988; 7: 645-50.

15 Vaira D, Holton J, Falzon M, et al. Decreased antibody titres to Campylobacter pylori (CP) after treatment of gastritis. $\mathrm{Br} \mathrm{Med} \mathrm{J} \mathrm{1988;} \mathrm{297:} 397$. 